\title{
THE GMINA REFERENDUM IN THE LOCAL POLITICAL CONFLICT. THE CASE OF WAŁBRZYCH
}

\author{
KAMIL GLINKA \\ Institute of Political Sciences, University of Wroclaw, ul. Koszarowa 3, \\ Wroclaw, Poland \\ E-mail address: kamil.glinka1@wp.pl
}

\begin{abstract}
The Gmina referendum is one of the main institutions of direct democracy in Poland. Its procedure laid down in the act of $15^{\text {th }}$ September 2000. The referendum is an expression of inhabitants' commitment and their concern about the functioning of a local community, as well as serving its basic needs and interests. The analysis of the political conflict in Wałbrzych during 2010-2011 shows, however, that the voting may play a different role. The main aim of the article is to present the correlation between the gmina referendum from 2011 and the conflict in question. The intention of the author is to establish whether the referendum exerted a real impact on the course and the results of the conflict in Wałbrzych, and if so, to what extent. The time frame of the article lies between, on the one hand, the local government elections of 2010 preceded by the election campaign, and, on the other hand, the repeated elections for the President of Town and for the Town Council of 2011.
\end{abstract}

Keywords: Gmina referendum, direct democracy, political conflict, election, local community

\section{INTRODUCTION}

The Gmina (commune) referendum is one of the main institutions of direct democracy in Poland. Its procedure is stipulated in the act from $15^{\text {th }}$ September 2000 (Journal of Laws 2000, no 88, item 985). The referendum is an expression of inhabitants' commitment and their concern about the functioning of a local community, as well as serving its basic needs and interests. Especially, due to the fact that it is an instrument for influencing the local authorities' decisions which do not satisfy social expectations (Piasecki, 2005, p. 81; Cf. Piasecki, 2006). However, the holding of a referendum may be regarded as a sign of the local political conflict engaging the members of a local community (Dzieniszewska-Naroska, 2012).

The aim of the article is to analyse the role and the importance of the Gmina referendum in the local political conflict in Wałbrzych during 2000-2011. Its time frame lies 
between, on the one hand, the local government elections from 2010 preceded by the election campaign, and, on the other hand, the repeated elections for the President of Town and for the Town Council from 2011. The intention of the author is to present the correlation between the Gmina referendum from 2011 and the shape of the conflict in Wałbrzych. In order to examine this issue one has to define the three fundamental elements of the conflict: its subject, sides and results (Cf. Sajelko-Szyszczak, 2011). Moreover, one needs to present the most important conditions of the organisation of Gmina referendum, its main types and the official data concerning such a form of direct democracy.

\section{THE GMINA REFERENDUM AS A FORM OF DIRECT DEMOCRACY}

The holding of Gmina referendum, treated as a sign of citizen participation of local communities' members (Piasecki, 2008), requires the fulfillment of specific conditions. The referendum may be held at the suggestion of gmina inhabitants, as well as at the initiative of the decision-making organ of a gmina which is a gmina council. Taking into account the referendums suggested by inhabitants, one needs to clarify the two important issues.

First of all, referendum initiators are defined by a legislator as the group of at least five inhabitants entitled to vote for the members of a gmina council, the statutory structure of a political party which functions in the gmina, or the social organisation which has the legal personality and operates in the gmina. The motion calling for a referendum proposed by the initiators needs to be supported by at least $10 \%$ of inhabitants (Journal of Laws 2000, no 88, item 985).

Secondly, a legislator distinguishes two types of referendums. The division is based on the different issues which are to be resolved by voting.

The first one is a referendum of an optional nature in which inhabitants are treated as "the members of a local community" and they express their "will concerning the way of solving the issue related to the community, being in the scope of tasks and competences of a given unit's organs" (Journal of Laws 2000, no 88, item 985). In practice it means that inhabitants may vote on all the issues which are important from their point of view (Jachimowicz, 2009). As far as Izabela Lewandowska-Malec is concerned, such a situation raises doubts for scholars dealing with the subject in question, as well as for administrative courts. Especially, taking into account the unclear interpretation of the "tasks of the unit's organs", namely a gmina (2011). The doubts have been dispelled only to certain extent by a legislator who passed the amendment dated $15^{\text {th }}$ September 2000. Especially, due to the fact that the legislator, by indicating "other important issues concerning social, economic and cultural ties binding (...) a community" (Journal of Laws 2013, item 153), broadened, in fact, the range of problems which may be the subject of a referendum of an optional nature (Bochetyn, 2013). It can be observed as the above-mentioned issues do not have to be in the scope of tasks and competences of a gmina.

In the course of the referendum of an obligatory nature, inhabitants may decide on two subjects. The first one is the self-imposition of taxes on inhabitants with the aim of aiding social goals, while the second is the shortening of the term of office of gmina's organs: a voyt, a mayor, a president of town as an executive authority or the previously-mentioned council (Journal of Laws 2000, no 88, item 985). 
A referendum is deemed effective when at least a half of all valid votes support the issue in question. The exception is the referendum concerning the self-imposition of taxes on inhabitants as its result is decisive and legally binding when there are at least $2 / 3$ of votes for. Whereas the referendum is considered valid only when at least $30 \%$ of all gmina's inhabitants entitled to vote participate in it. The situation differs when it comes to the so-called recall referendum, when $3 / 5$ of inhabitants have to cast their votes (Journal of Laws 2000, no 88, item 985).

Regarding the multitude of the problems discussed, it is difficult to prepare a uniform system of referendums of an optional nature embracing the whole country (Kowalik, 2010). Such a task transcends the subject of the article. Especially, as Bogdan Dolnicki ephasises, the scope of issues which cannot constitute the subject of such a referendum is very limited, as it includes the change of budget or taxes, the taking of administrative decisions or the fulfillment of the delegated tasks from the area of government administration (2012).

The data obtained from Państwowa Komisja Wyborcza (the National Electoral Commission) shows that, in contrast to optional referendums, the system of referendums of an obligatory nature proves to be possible. Especially, when taking into account one type of such referendum, namely the so-called recall referendum. According to Andrzej K. Piasecki, they account for about $85 \%$ of all the conducted referenda (2008b). What results from Table 1, presenting the number and the results of referenda concerning the recall of the local self-government units' organs during 2010-2013, one may observe that their effectiveness is relatively small. In case of voting concerning the recall of a voyt, a mayor or a president, the result is $12 \%$, while the recall of a council - merely $12 \%$. Such a low effectiveness of the so-called recall referendum seems to justify the question whether they have the power to influence the dynamics of local political conflicts, including the conflict in Wałbrzych during 2010-2012. Especially due to the fact that, as Table 1 presents, they do not lead to a change of authorities.

\begin{tabular}{|l|l|l|l|l|l|}
\hline \multirow{2}{*}{ Recalled authority } & \multicolumn{5}{|c|}{ Referendum } \\
\cline { 3 - 6 } & \multirow{2}{*}{ conducted } & \multicolumn{4}{|c|}{ including } \\
\cline { 3 - 6 } & & valid & invalid & \multicolumn{2}{|c|}{ including } \\
\cline { 5 - 6 } & & & & effective & ineffective \\
\hline $\begin{array}{l}\text { A gmina council, } \\
\text { a powiat council }\end{array}$ & $19(24 \%)$ & $2(11 \%)$ & $17(89 \%)$ & $2(11 \%)$ & $17(89 \%)$ \\
\hline $\begin{array}{l}\text { The voyt, } \\
\text { the mayor, } \\
\text { the president of town }\end{array}$ & $59(76 \%)$ & $7(12 \%)$ & $52(88 \%)$ & $7(12 \%)$ & $52(89 \%)$ \\
\hline Total & $78(100 \%)$ & $9(12 \%)$ & $69(88 \%)$ & $9(12 \%)$ & $69(88 \%)$ \\
\hline
\end{tabular}

Table 1. The referenda concerning the recall of the local local government units' organs in Poland during 2010-2013 - data in numbers and percentage (\%). 


\section{POLITICAL CONFLICT}

The phenomenon of conflict a the subject of scientific interest for representatives of various scientific disciplines: sociology, political science, psychology, cultural studies, law, history, international relations etc. It is due to the fact that conflict seems to be present in all spheres of life. The meaning of Latin word conflictus (collision) allows one to claim that conflict is a kind of contradiction, disagreement between sides. Disregarding the detailed classifications elaborated by scientists (Cf. Sztumski 2000), one may claim that conflict is „a situation in which all kinds of behaviour and actions undertaken by units or groups aim at gaining any benefits against the will of other units or groups" (Kotarba, 2008, p. 283).

The analysis of subject literature presents that, regarding the subject of disagreement, one may distinguish a few main types of conflicts i.a.: social, economic, ideological, class, cultural, aksiological, teleological (Cf. Sztumski, 1987; Fink, 1968). The researchers agree that it is justifiable to mention a political conflict as well. They base their view on a few factors. The main role is played, however, by the nature of politics itself, described aptly as the aspiration for gaining and maintaining power (cf. Brickman, 1974). Therefore, conflict seems to be unavoidable in politics, as it constitutes its immanent part. Conflict, which is perceived as the contradictory aspirations of two or more political subjects, can be found on different levels: international, home, regional and local. Its main cause is usually the realised divergence, the contradiction of the units' interests (Kuświk, 2012). As Leszek Sobkowiak emphasises, the vast majority of conflicts are not political ones. Nevertheless, the growing difficulties with solving the problems of social, economic, cultural nature lead to the situation in which with time they start to be political conflicts (cf. Sobkowiak, 1996). In consequence, they engage the members of the competition for power, irrespective of the fact of whether it is during an election period, or not. The situation in Wałbrzych during 2010-2011 is an example of the conflict whose source was the competition for power.

Political conflicts may take different forms, and, in extreme cases, may lead to the use of violence. The analysed case, however, concerns the conflict entailing the political competition concerning the election period which proceeds in accordance with the rules of democracy.

The subject criterion, however, is not the only one which may be applied in order to classify conflicts, including political conflicts. Adopting the criterion of the number of members (sides), one should mention unit and group conflicts (Buchanan \&Huczyński, 1997). The analysis of the conflicts' causes enables one to establish a different division, namely for objective and subjective conflicts (Lan, 1985). Witold Kieżun, however, assumes that the criterion of cause leads to the division for emotional and material conflicts. The first ones result from the interaction between the units and the groups, while the second one stems from the different opinions concerning the possible ways of solving a given problem (1997). Taking into account the results of a conflict, one may speak about constructive and destructive conflicts (Kuc, 1999). Moreover, focusing on the results may result in adopting the division for effective, ineffective and counter effective conflicts. The counter effective ones, due to their nature, do not allow one to achieve the intended, planned results, irrespective of the undertaken actions (Sztumski, 1987).

\section{GMINA REFERENDA IN WAŁBRZYCH}

As Table 2 presents, Gmina referenda, treated as an expression of inhabitants' commitment and concern about local issues, have rarely been conducted in Wałbrzych, actually only twice. While the voting in 2012 was the so-called recall referendum, the one in 2011 concerned a different issue important from the inhabitants' point of view. 
The time frame and the shape of the analysed political conflict make the referendum of 2011 the subject of the author's work.

\begin{tabular}{|l|l|l|}
\hline & \multicolumn{2}{|c|}{ Conducted referendums } \\
\hline Years & $\begin{array}{c}\text { Concerning the dismissal of } \\
\text { the local self-government } \\
\text { unit's organ }\end{array}$ & $\begin{array}{l}\text { Concerning other issues than } \\
\text { the dismissal of the local } \\
\text { self-government unit's organ }\end{array}$ \\
\hline $1990-1994$ & 0 & 0 \\
\hline $1994-1998$ & 0 & 0 \\
\hline $1998-2002$ & 0 & 0 \\
\hline $2002-2006$ & 0 & 0 \\
\hline $2006-2010$ & 0 & 0 \\
\hline $2010-2013$ & 1 & 1 \\
\hline
\end{tabular}

Table 2. Gmina referenda in Wałbrzych during 1990-2013

Source: data prepared by the author on the basis of: KWa; KWb; KWc; KWd; KWe; UM, 2011.

It would be a mistake to claim that earlier there have not been any attempts to organise referenda. On the contrary, referenda were held in 2000 and 2008. In the case of the first one, its initiators stepped back from proposing the motion for voting, while in 2008 they failed to collect the required $10 \%$ of signatures supporting their initiative. Therefore, both of the attempts were inconclusive.

\section{POLITICAL CONFLICT AND GMINA REFERENDA IN WAŁBRZYCH}

Assuming that political conflict may be defined as the contradictory aspirations of two or more subjects of politics, one may state that the sides of conflict in Wałbrzych were the authorities of the town and their opposition. Taking into account the period of the analysed conflict, one should emphasise that the source of the competition for power was made visible by the local government elections, namely the election campaigns defined as the marketing actions, techniques and means aiming at the provision of information on a candidate (cf. Mazur, 2002).

Table 3 presents the members of the campaign which preceded the elections for the President of Town and the Town Council in 2010. The marketing actions targeted at the inhabitants of Wałbrzych were undertaken by, in both cases, seven committees. Obviously, in the second round of elections for the President of Town only two of them competed with each other. In the run-up to elections the sides of conflict were, therefore, the campaign committees mentioned in Table 3. Especially due to the fact that about one month before the elections there was a breakdown of coalition in the Town Council formed by Civic Platform (Platforma Obywaltelska, PO) and Law and Justice (Prawo i Sprawiedliwość, PiS). In consequence, both parties formed separate campaign committees. 


\begin{tabular}{|c|c|c|c|}
\hline \multicolumn{2}{|r|}{ President of Town } & \multicolumn{2}{|r|}{ Town Council } \\
\hline $\begin{array}{r}21 . \\
11 . \\
2010\end{array}$ & $\begin{array}{l}\text { 1. Mirosław Lubiński (KWW } \\
\text { Wałbrzyska Wspólnota } \\
\text { Samorzadowa) - } 26,80 \% \\
\text { 2. Piotr Kruczkowski (KW Platforma } \\
\text { Obywatelska RP) - 25,70\% } \\
\text { 3. Patryk Wild (KWW Patryk Wild) - } \\
\text { 18,60\% } \\
\text { 4. Henryk Gołębiewski (KW Sojusz } \\
\text { Lewicy Demokratycznej) - } 10,71 \% \\
\text { 5. Piotr Sosiński (KW Prawo i } \\
\text { Sprawiedliwość) - 9,78\% } \\
\text { 6. Bogusława Czupryn (KWW } \\
\text { Klubu Inicjatyw Społecznych } \\
\text { Mieszkańców Wałbrzycha) - 5,07\% } \\
\text { 7. Andrzej Zibrow (KWW Andrzeja } \\
\text { Zibrowa Dobry Samorząd) - 3,80\% }\end{array}$ & $\begin{array}{r}21 . \\
11 . \\
2010\end{array}$ & $\begin{array}{l}\text { 1. KW PO - } 9 \\
\text { 2. KWW WWS - } 7 \\
\text { 3. KW SLD - } 5 \\
\text { 4. KW PiS - } 4 \\
\text { 5. KW Patryk Wild } \\
\text { Nowoczesny } \\
\text { Wałbrzych - } 0 \\
\text { 6. KWW KISMW - } 0\end{array}$ \\
\hline $\begin{array}{r}5 . \\
12 . \\
2010\end{array}$ & $\begin{array}{l}\text { 1. Piotr Kruczkowski (KW PO) - } \\
\text { 50,59\% } \\
\text { 2. Mirosław Lubiński (KW WWS) - } \\
49,41 \%\end{array}$ & & 7. KWW AZ DS - 0 \\
\hline
\end{tabular}

Table 3. Local government elections in Wałbrzych in 2010 - candidates and results Source: PKWb.

The decision of District Court in Świdnica concerning the repetition of the elections for the President of Town and partially for the Town Council led to the situation in which in 2011 local mass media broadcasted the next election campaign (Mykytyszyn, 2010). As Table 4 shows, only four of the committees proposed their candidates for the President of Town. The number of campaign committees proposing their candidates for the Town Council did not change as there were seven of them. The data from Table 3 and Table 4 clearly present that in the course of nearly a year the number of conflict sides declined only in case of the elections for the President of Wałbrzych.

\begin{tabular}{|c|c|c|c|}
\hline \multicolumn{2}{|r|}{ President of Town } & \multicolumn{2}{|c|}{ Town Council (district 5) } \\
\hline $\begin{array}{c}7 . \\
08 . \\
2011\end{array}$ & $\begin{array}{l}\text { 1. Roman Szełemej (KWW Romana } \\
\text { Szełemeja) - 60,35\% } \\
\text { 2. Patryk Wild (KWW Patryk Wild) - } \\
\text { 20,61\% } \\
\text { 3. Mirosław Lubiński (KWW Mirosława } \\
\text { Lubińskiego) - 13,95\% } \\
\text { 4. Kamil Zieliński (KW PiS) - 5,09\% }\end{array}$ & $\begin{array}{c}11 . \\
09 . \\
2011\end{array}$ & $\begin{array}{l}\text { 1. KW PO - } 1 \\
\text { 2. KWW WWS - } 1 \\
\text { 3. KW SLD - } 2 \\
\text { 4. KW PiS - } 1 \\
\text { 5. KWW Patryk Wild - } 0 \\
\text { 6. KWW KISMW - } 0 \\
\text { 7. KWW AZ DS - } 0\end{array}$ \\
\hline
\end{tabular}

Table 4. The early elections for the President of Town and the repeated elections for Town Council in 2011 - candidates and results (\%) Source: PKWc, PKWd. 
The core of politics, defined as the aspiration for gaining or maintaining power, presents in a clear manner not only the fundamental cause, but also the subject of the conflict in Wałbrzych. The analysis of the election campaigns from 2010 and 2011 shows, however, that the members of the political competition indicated a number of the issues deciding upon the shape and the nature of the conflict. It is difficult to assess clearly whether they were connected to the pre-election marketing actions, or were the result of the real opinions and attitudes of the candidates. Table 6 depicts the most important subjects of the two election campaigns in question.

\begin{tabular}{|l|l|}
\hline Campaign & \multicolumn{1}{c|}{ Subjects } \\
\hline \multirow{2}{*}{2010} & $\begin{array}{l}\text { - the regaining the status of the town with powiat (district) rights } \\
\text { - the prices of town water and municipal waste water } \\
\text { - the investments in sport and recreation infrastructure } \\
\text { - the investments in road infrastructure } \\
\text { - the town promotion } \\
\text { - the storage of hazardous waste in the town } \\
\text { - the transit of large goods vehicles through the town } \\
\text { - the town revitalisation } \\
\text { - the reconstruction of the town housing stock } \\
\text { - high unemployment rate in the town } \\
\text { - creating new jobs } \\
\text { - attracting new investors } \\
\text { - the functioning of the Wałbrzych Special Economic Zone } \\
\text { "Invest Park" } \\
\text { - the party affiliation of the candidates for the president of town }\end{array}$ \\
\hline 2011 & $\begin{array}{l}\text { - do. } \\
\text { - the problem of "vote-buying" } \\
\text { - electoral fraud } \\
\text { - inappropriate behaviour of politicians }\end{array}$ \\
\hline
\end{tabular}

Table 5. Chosen subjects of local election campaigns in Wałbrzych during 2010-2011. Source: data prepared by the author.

As it is presented in Table 5, the members of the political competition addressed a relatively large number of subjects which, from their point of view, seemed to be important for the functioning of the town and its inhabitants. The analysis of the information provided in the table deserves, however, clarification. In both of the campaigns the number of the subjects were almost the same. Nevertheless, one should mention the three issues which distinguish the subject matter of the campaign from 2011 from the one in 2010. Namely, in 2011 the attention of the mass media was focused on the candidates' statements concerning the problem of "vote-buying", the electoral fraud and the inappropriate behaviour of local politicians.

While conducting the analysis of the local political conflict during 2010-2011 it should be stressed that its most important, long-term result was the change of the President of Town. In spite of the fact that running for re-election Piotr Kruczkowski 
won the vote in 2010, in 2011 it was Roman Szełemej who became the President of Wałbrzych. He was an independendent candidate supported by Civic Platform (PO). While comparing the two sets of voting results, it can be stated that there was a slight change in the number of seats held by the political parties represented in the Town Council of Wałbrzych. As results from Table 3 and Table 4, PO lost one seat in favour of Democratic Left Alliance (Sojusz Lewicy Demokratycznej-SLD). After the elections in 2010 the new coalition was formed in the Town Council by PO, having the majority of seats, and SLD. The repeated elections in district 5 held in 2011 did not bring any changes in this respect.

The first Gmina referendum in Wałbrzych was held on $13^{\text {th }}$ February 2011. Its initiators were the inhabitants forming Grupa Inicjatywna "Nowoczesny Wałbrzych" (the Initiative Group "Modern Wałbrzych"). The referendum concerned the three issues. The first one was the idea to subsidise the water and municipal waste water from the town budget. The second issue concerned the ban on hazardous waste storage in Wałbrzych, while the third question was related to the the transit of large goods vehicles through the town (Maciejewski, 2011).

The voting was preceded by the campaign attracting the attention of the local mass media. Althought the majority of voters answered 'yes' to the three questions, the referendum was ineffective due to the low turnout of 18,76\% (Nasze-miasto.pl, Szczegótowe wyniki referendum w Wałbrzychu [Detailed Results of the Referendum in Wałbrzych], (http://walbrzych.naszemiasto.pl/artykul/szczegolowe-wynikireferendum-wwalbrzychu,7787 8 2,t,id.html).

The date of the referendum allows one to claim that it was held during the local political conflict in question. Especially, taking into account the time frame of the conflict which lies between the elections of 2010 and 2011. However, in order to assess the correlation between the referendum and the conflict one has to answer a few questions.

The first question is what decided the inhabitants' interest in the referendum presented by the conflict sides? Secondly, did the conflict sides take a stand on the referendum subject? Last but not least, was there a correlation between the presented attitude towards the referendum subject and the conflict result?

Undoubtedly, the main aim of the above-mentioned campaign was to increase the inhabitants interest in the participaton in the referendum. The analysis of the local press, Internet websites and channels shows, however, that there was a different factor which attracted interest.

Thanks to one of the conflict sides, the issues related to the prices of water and municipal waste water, the storage of hazardous waste and the transit of large goods vehicles became the crucial elements of the conflict. It was due to Patryk Wild, a candidate for the President of Wałbrzych in 2010 and 2011 and, at the same time, the member of initiative group which proposed the motion for the referendum (Pawłowski, 2010).

All three questions which constituted the subject of referendum were, at the same time, the elements of P. Wild's election programme, proposed during campaigns in 2010 and 2011. Among the most important points of the programme called Priorytety dla Watbrzycha (The priorities for Watbrzych) one could find the ideas directly referring to the questions of the referendum. The first point was to "liquidate the hazardous waste storage Mo-Bruk", while the second to" repair the pipe networks and limit leakage losses, and to subsidise the costs from the town budget until the repair is completed" (NWa). 
Moreover, such a convergence was supported in P. Wild's statements presented to the general public. The fragments of the numerous interviews for local mass media during 2010-2011 may serve as examples. In October 2010 P. Wild, as a candidate for the President of Town, presented his stand concerning the price of water in Wałbrzych. He tried to persuade that: "We claim that it is absolutely immoral (...) that the inhabitants of Wałbrzych pay for water the mostly from the big towns of Lower Silesia, and have to incur the costs of the weakness in managing the water system" (YouTube, Patryk Wild o wodzie w Wałbrzychu [Patryk Wild about water in Wałbrzych]. (http://www. youtube.com/watch? $\mathrm{v}=\mathrm{zx} 90 \mathrm{dZOFz3c}$ ). A month later he presented his opinion on the hazardous waste storage in Wałbrzych, as he claimed that "The firm is already known by the inhabitants from its worst side and the truth is that there is no hope that it will improve its image" (Daminfo.pl, Stanowcze nie dla ekspansji firmy Mo-Bruk w Watbrzychu [Firm No to the Expansion of Mo-Bruk Company in Wałbrzych]. (http://www.daminfo.pl/component/k2/item/3155-stanowcze-nie-dla-ekspansji-firmy-mo-bruk -w-walbrzychu). In June 2011, four months after the referendum, he formulated his idea to solve the problem of the large goods vehicle transit through Wałbrzych. He stated that "the problem can be solved easily (...) The people ruling Wałbrzych do not want to solve it because there could have been a ban on the entry of vehicles above 5 tonnes months ago (...) It would not require any compensation" (NWb). The same or similar ideas were presented by the members of his committee, running for the elections for the Town Council. What is crucial, in 2010 the committee had the same name as the already mentioned initiative group which put the motion for the referendum. In both cases the name was Nowoczesny Wałbrzych - Modern Watbrzych (cf. Table 3).

The actions of P. Wild and his associates forced the conflict sides to take their stand in the issues concerning the prices of water and municipal waste water, the localisation of hazardous waste storage and the large goods vehicles transit in the town. Therefore, all the most important members of the political competition responded to the three issues of the voting. The statements of the candidates for the President of Town from November 2010 may serve as examples. As Table 6 depicts, the candidates, including Patryk Wild, supported the idea of the liquidation of the hazardous waste storage.

The analysis of the data presented in Table 3 and Table 4 presents the lack of direct correlation between the result of the political conflict in Wałbrzych and the presented stand concerning the referendum subject. The result achieved by P. Wild, the initiator of the referendum and the candidate for the President of Town, serves as an example. In spite of the clear support for, not only the holding of the referendum, but also the three subjects of the voting, P. Wild did not become a president. Moreover, the members of his committee running for the elections for the Town Council did not win a single seat.

\section{SUMMARY}

The Gmina referendum, which is a main form of direct democracy in Poland, may be perceived as a sign of inhabitants' engagement in the functioning of the local community. Such a view proves to be true in case of Wałbrzych as well. The analysis of the sides, subject and results of the political conflict in Wałbrzych during 2010-2011 shows, however, that the referendum from February 2011 played also a different role. Especially, when one takes into account the course of the conflict in question. 


\begin{tabular}{|c|c|c|}
\hline $\begin{array}{l}\text { Candidate and } \\
\text { campaign committee }\end{array}$ & $\begin{array}{l}\text { Yes/No for } \\
\text { liquidation }\end{array}$ & Justification \\
\hline $\begin{array}{c}\text { Mirosław Lubiński } \\
\text { (KWW Wałbrzyska } \\
\text { Wspólnota } \\
\text { Samorządowa) }\end{array}$ & Yes & $\begin{array}{l}\text { "It's unthinkable that in the town centre } \\
\text { there is a ticking ecological bomb. We do } \\
\text { not agree with the poisoning of people } \\
\text { and the environment". }\end{array}$ \\
\hline $\begin{array}{l}\text { Piotr Kruczkowski } \\
\text { (KWW Platforma } \\
\text { Obywatelska) }\end{array}$ & Yes & $\begin{array}{l}\text { "The predecessors' decision concerning } \\
\text { the localisation of the investment in the } \\
\text { town was a mistake". }\end{array}$ \\
\hline $\begin{array}{c}\text { Patryk Wild } \\
\text { (KWW Patryk Wild) }\end{array}$ & Yes & $\begin{array}{l}\text { "Its functioning and the recurring } \\
\text { fires are a great and unprecedented } \\
\text { scandal which may be described in just } \\
\text { one sentence: Some earn huge sums of } \\
\text { money, while the others die of cancer". }\end{array}$ \\
\hline $\begin{array}{l}\text { Henryk Gołębiewski } \\
\text { (KWW Sojusz Lewicy } \\
\text { Demokratycznej) }\end{array}$ & Yes & $\begin{array}{l}\text { "Taking into account the responsibility } \\
\text { for the environment in which our town's } \\
\text { inhabitants live and the duty to provide } \\
\text { standards of living and development } \\
(\ldots)^{\prime \prime} \text {. }\end{array}$ \\
\hline $\begin{array}{l}\text { Piotr Sosiński } \\
\text { (KW Prawo i } \\
\text { Sprawiedliwość) }\end{array}$ & Yes & $\begin{array}{l}\text { "Undoubtedly, it would be better if the } \\
\text { hazardous waste storage hadn't been } \\
\text { located in our town". }\end{array}$ \\
\hline $\begin{array}{l}\text { Bogusława Czupryn } \\
\text { (KWW KIS } \\
\text { Mieszkańców } \\
\text { Wałbrzycha) }\end{array}$ & Yes & "It should be liquidated". \\
\hline $\begin{array}{l}\text { Andrzej Zibrow } \\
\text { (KWW Andrzej Zibrow } \\
\text { Dobry Samorząd) }\end{array}$ & Yes & $\begin{array}{l}\text { "We should limit the functioning of the } \\
\text { storage, and, in the end, liquidate it". }\end{array}$ \\
\hline
\end{tabular}

Tab. 6. The opinion of the candidates for the president of Wałbrzych in 2010 regarding the liquidation of the hazardous waste storage. 
First of all, as results from the data presented in the other part of the article, the Gmina referenda held in Wałbrzych did not exert a direct influence on the result of the political conflict whose boundaries were the elections in 2010 and 2011. Such a conclusion can be drawn on the basis of the results achieved by P. Wild, as well as other members of his campaign committee. The results clearly illustrate the lack of the positive correlation between the officially presented attitude towards the referendum's subject and the final outcome of the political competition. Such an observation should be emphasized due to the fact that Patryk Wild was the initiator of the analysed referendum.

Secondly, the lack of the correlation between the referendum and the result of the conflict in Wałbrzych proves that the voting did not have any impact on the conflict's course. On the contrary, taking into consideration the three issues: the prices of water and municipal waste water, the hazardous waste storage and the transit of large goods vehicles in the town, one is allowed to claim that they did not constitute the subjects of real interest of the conflict sides. The interest was not attracted by the campaign organized by the initiative group, but by the political actions of P. Wild, who was one of the main sides of the conflict in Wałbrzych. The opinions concerning the subject of the referendum expressed by other conflict sides resulted from Wild's actions, not the referendum campaign.

Therefore, the Gmina referendum in Wałbrzych, engaging the attention of the sides of political conflict during 2010-2011, may be perceived, on the one hand, as an instrument of the competition for power in the town, and on the other hand, as one of the main subjects of the electoral campaign in 2010 and 2011. Especially, when one takes into account the two issues. First of all, the three questions constituting the subject of the referendum became, in fact, one of the main points of the conflict. Secondly, the questions attracted the attention of the local mass media and, hence, of the town's inhabitants treated as voters.

\section{REFERENCES}

Bochetyn, A. (2013). Referendum lokalne z szerszym zakresem poruszanych spraw [Local Referendum with a Wider Range of Issues in Question]. Retrieved from http://www.samorzad.lex.pl/czytaj/-/artykul/ referendum-lokalne-z-szerszym-zakresemporusza nych-spraw-1.

Brickman, P. (1974). Rule Structure and Conflicts Relationships. In: P. Brickmann (Ed.), Social Conflict (pp. 1-36). Lexington: D. C. Health.

Buchanan, D., \& Huczyński, A. (1997). Organizational Behaviour. Glasgow: Prentice Hall.

Daminfo.pl (2010). Stanowcze nie dla ekspansji firmy Mo-Bruk w Wałbrzychu [Firm No to the Expansion of MoBruk Company in Wałbrzych]. Retrieved from http://www.daminfo.pl/component/k2/item/3155stanowcze-nie-dla-ekspansji-firmy-mo-bruk -w-walbrzychu.

Dolnicki, B. (2012). Samorzad terytorialny [Local Government]. Warszawa: Wolters Kluwer.

Dz. U. 2000, nr 88, poz. 985, Ustawa z dnia 15 września 2000 r. o referendum lokalnym [Journal of Laws from 2000, No 88, item 985, Resolution from $15^{\text {th }}$ September 2000 on local referendum].

Dz. U. 2013, poz. 135, Ustawa z dnia 14 grudnia 2012 r. o zmianie ustawy o referendum lokalnym oraz ustawy o samorządzie gminnym [Journal of Laws from 2013, item 135, Resolution from 14th December 2012 concerning the changing of the resolution on local referendum and the resolution on gmina government].

Dzieniszewska-Naroska, K. (2012). Konflikty polityczne a partycypacja na przykładzie referendów w sprawie odwołania władz [Political Conflicts and Participation - the Example of Referendums Concerning the Recalling of Authority]. In: A. Olech (Ed.), Dyktat czy uczestnictwo? Diagnoza partycypacji publicznej w Polsce 
[Diktat or Participation? The Diagnosis of the Public Participation in Poland] (pp. 274-287). Warsaw: ISP.

Fink, C. F. (1968). Some Conceptual Difficulties in the Theory of Social Conflict. Journal of Conflict Resolution, 12 (4), 412-460.

Jachimowicz, M. (2005). Przestępstwa i wykroczenia z ustawy o referendum lokalnym [Crimes and Offence Based on the Resolution on Local Referendum]. Studia Lubuskie, 1 [Lubuskie Studies, 1]. 109-120.

Kieżun, W. (1997). Sprawne zarzadzanie organizacją [Effective Management of an Organisation]. Warsaw: SGH. Kotarba, B. (2008). Wpływ konfliktów w samorządzie gminnym na zachowanie spójności społecznoekonomicznej gminy [The Influence of Conflicts in a Gmina Government on the Social and Economic Coherence of a Gmina]. In: M. G. Woźniak (Ed.), Nierówności społeczne a wzrost gospodarczy [Social Inequalities vs. Economic Growth] (pp. 279-294). Rzeszow: University of Rzeszow Press.

Kowalik, J. (2010). Aktywność obywateli w samorządzie gminnym z perspektywy władz lokalnych [Inhabitants' Activity in a Gmina Government from the Perspective of Local Authorities]. Annales Uniwersitatis Mariae Curie-Skłodowska Lublin - Polonia. Sectio K, 17 (1), 85-106.

Kuc, B. R. (1999). Zarzadzanie doskonałe [Perfect Management]. Warsaw: SGH.

Kuświk, J. (2013). Konflikt polityczny z perspektywy teorii zachowania zasobów [The Political Conflict from the Perspective of the Conservation of Resources Theory]. Środkowoweuropejskie Studia Polityczne, 2 [Central European Political Studies, 2]. 329-341.

KWa. (n.d.). Komisarz Wyborczy w Wałbrzychu. Zestawienie inicjatyw referendalnych oraz referendów gminnych w sprawie odwotania rad gmin na obszarze właściwości terytorialnej Komisarza Wyborczego w Watbrzychu w kadencjach 1990-1994, 1994-1998 oraz 1998-2002 [Election Commissioner in Wałbrzych. The Compilation of Referendum Initiatives and Gmina Referendums Concerning the Recalling of City Councils in the Area of the Election Commissioner in Wałbrzych in the Tenures 1990-1994, 1994-1998 and 1998-2002]. Retrieved February 28, 2013, from http:/ / walbrzych.pkw.gov.pl/archiwum-892/referenda-gminne-.html.

$K W b$. (n.d.). Komisarz Wyborczy w Wałbrzychu. Zestawienie referendów lokalnych w trakcie kadencji 20022006 [Election Commissioner in Watbrzych. The Compilation of Local Referendums During the Tenure 20022006]. Retrieved February 28, 2013, from http://walbrzych.pkw.gov.pl/referenda-lokalne-1912/wyniki-referendowlokalnych.html.

KWc. (n.d.). Komisarz Wyborczy $\mathrm{w}$ Wałbrzychu. Inicjatywy referendalne $\mathrm{w}$ sprawie odwołania organu jednostki samorządu terytorialnego przed upływem kadencji w latach 2006-1010 [Election Commissioner in Watbrzych. Referendum initiatives Concerning the Recalling of the Local Government Unit Before the End of a Tenure in the Years 2006-1010]. Retrieved February 28, 2013, from http://walbrzych.pkw.gov.pl/referendalokalne-1912/inicjatywy-referendalne-w-sprawie-odwolania-organu-jednostki-samorzadu-terytorialne go-przeduplywem-kadencji-w-latach-2006-1010.html.

KWd. (n.d.). Komisarz Wyborczy w Wałbrzychu. Zestawienie wyników referendów lokalnych - kadencja 2006-2010 [Election Commissioner in Watbrzych. The Compilation of the Local Referendums' Results - Tenure 2006-2010]. Retrieved February 28, 2013, from http://walbrzych.pkw.gov.pl/referenda-lokalne-1912/zestawieniewynikow-referendow-lokaln ych-kadencja-2006-2010.html.

KWe. (n.d.). Komisarz Wyborczy w Wałbrzychu. Referenda lokalne w sprawie odwołania organów jednostek samorzadu terytorialnego przed uptywem kadencji. Kadencja 2010 - 2014 [Election Commissioner in Wałbrzych. Local Refrendums Concerning the Recalling of Local Government Units Before the End of a Tenure. Tenure 2010 - 2014]. Retrieved February 28, 2013, from http:/ / walbrzych.pkw.gov.pl.

Lan, Z. (2005). A Conflict Resolution Approach to Public Administration. In: J. Beckett, H. O. Koenig (Eds.). Public Administration and Law (pp. 189-204). New York: American Society for Public Administration.

Lewandowska-Malec, I. (2011). Skutek prawny referendum lokalnego [The Legal Effect of a Local Referendum]. Studia Prawnicze. Rozprawy i Materiaty, 7 [Legal Studies. Hearings and Materials, 7]. 99-113.

Maciejewski, M. (2011). Referendum w Wałbrzychu [Referendum in Wałbrzych]. Retrieved from http:/ / www. tvp.pl/wroclaw/aktualnosci/rozmaitosci/referendum-w-walbrzychu/3891561.

Mazur, M. (2002). Marketing polityczny. Studium porównawcze prezydenckich kampanii wyborczych w USA i w Polsce 
Journal of Education Culture and Society No. 2_2014

[Political Marketing. The Comparative Study of the Presidential Campaigns in USA and Poland]. Warsaw: PWN. Mykytyszyn, M. (2010). Kampania skandalem ożywiona [The Campaign Enlivened by Scandal]. Wiadomości Wałbrzyskie, 49 [New Wałbrzych News, 49]. 3.

Nasze-miasto.pl (2011). Szczegótowe wyniki referendum w Wałbrzychu [Detailed Results of the Referendum in Wałbrzych]. Retrieved from http://walbrzych.naszemiasto.pl/artykul /szczegolowe-wynikireferendum-wwalbrzychu,778782,t,id.html.

NWa. (n.d.). Nowoczesny Wałbrzych. Praca i rozwój [Modern Wałbrzych. Work and Development]. Retrieved February 28, 2013, from http:/ / www.nowoczesnywalbrzych.pl/ praca-i-rozwoj-program.html.

NWb. (n.d.). Nowoczesny Wałbrzych. Patryk Wild Rozmowa z TVT [Modern Wałbrzych. Patryk Wild Talk with TVT]. Retrieved February 28, 2013, from http://www.nowoczesnywalbrzych.pl/filmy-i-spoty/patrykwild-rozmowa-w-tvt-24-06-2011 .html.

Pawłowski, R. (2010). Chcą wałbrzyskiego referendum [They Want a Referendum in Wałbrzych]. Tygodnik Wałbrzyski, 37 [Wałbrzych Weekly, 37]. 3.

Piasecki, A. K. (2005). Demokracja bezpośrednia w Polsce lokalnej - błędny model, zła praktyka [Direct Democracy in Local Poland - Wrong Model, Wrong Practice]. Studia Regionalne i Lokalne, 3 [Regional and Local Studies, 3]. 67-84.

Piasecki, A. K. (2006). Referenda lokalne w Polsce jako przejaw populizmu czy społeczeństwa obywatelskiego? [Local Referendums in Poland - a Sign of Populism or Civil Society?]. In: M. Marczewska-Rytko (Ed.), Populizm na przełomie XX i XXI wieku. Panaceum czy pułapka dla wspótczesnych społeczeństw? [Populism at the Turn of 20th and 21st Centuries. Panacea or a Trap for the Modern Societies?] (pp. 177-195), Torun: Adam Marszałek Press.

Piasecki, A. K. (2008). Duty or Privilege? Participation Barriers on the Example of Local Votings. In: K. Łabędź (Ed.), The Barriers of Public Activity (pp. 69-85). Toruń: Adam Marszałek Press.

Piasecki, A. K. (2008b). Lokalna demokracja bezpośrednia [Local Direct Democracy]. In: E. Gapowicz, L. Rubisz (Eds.), Polityka lokalna. Wtaściwości, determinanty, podmioty [Local politics. Features, Determinants, Subjects] (pp. 240-257). Torun: Adam Marszałek Press.

Piasecki, T. (2010). Kandydaci na prezydencki tron odkrywają karty [The Candidates for President Show their Hands]. Nowe Wiadomości Wałbrzyskie, 45 [New Wałbrzych News, 45]. 16-17.

PKWa. (n.d.). Państwowa Komisja Wyborcza. Wybory i referenda lokalne w trakcie kadencji organów jednostek samorzadu terytorialnego. Statystyka kadencja 2010-2014 [National Electoral Commission. The Elections and Referendums during the Tenure of Local Government Units. Statistics Tenure 2010-2014]. Retrieved February 28, 2013, from http://pkw.gov.pl/kadencja-2010-2014/wybory-i-referenda-lokalne-w-trakciekadencji-organow-jednostek-samorzadu-terytorialnego-lata-20112012. html.

PKWb. (n.d.) Państwowa Komisja Wyborcza. Geografia wyborcza. Miasto Wałbrzych. Wyniki głos. i wyb. Prezydenta [National Electoral Commission. Electoral Geography. Wałbrzych. The Results of Voting for President]. Retrieved February 28, 2013, from http:// wybory2010.pkw.gov.pl/geo/pl/020000/022109.html\#tabs-6.

PKWc. (n.d.) Państwowa Komisja Wyborcza. Wybory przedterminowe prezydenta miasta Wałbrzycha w województwie dolnoślaskim zarządzone na dzień 7 VIII 2011 roku. National Electoral Commission [The Early Elections for President of Wałbrzych in Lower Silesia Province Planned for 7th August 2011]. Retrieved February 28, 2013, from http://www.kadencja.pkw.gov.pl/aw/pl/20110807-022109WBPP/.

PKWd. (n.d.) Państwowa Komisja Wyborcza. Wybory ponowne do Rady Miejskiej Wałbrzycha zarzadzone na dzień 11 IX 2011 - okreg nr 5 [National Electoral Commission. Repeted Elections to City Council of Wałbrzych planned for 11th September 2011 - District no 5]. Retrieved February 28, 2013, from http:/ / www.kadencja. pkw.gov.pl/aw/pl/20110911-022109-RDAO/index.html.

Sajelko-Szyszczak, I. (2011). Klasyfikacja konfliktów w przedsiębiorstwie [Classification of Conflicts in an Enterprise]. Acta Universitatis Nicolai Copernici. Zarzadzanie, 404 [Acta Universitatis Nicolai Copernici. Management, 404], 137-148.

Sobkowiak, L. (1996). Konflikt polityczny - analiza pojęcia [Political Conflict - Term Analysis]. In: A. W. 
Jabłoński, L. Sobkowiak (Eds.) Studia z teorii polityki, vol. 1 [Studies on Political Theory, vol. 1] (pp. 117131). Wroclaw: Wroclaw University Press.

Sztumski, J. (1987). Konflikt społeczny [The Social Conflict]. Katowice: Univeristy fo Silesia.

Sztumski, J. (2000). Konflikty społeczne i negocjacje jako sposoby ich przezwyciężania [Social Conflicts and Negotiations as the Ways of Overcoming]. Czestochowa: Czechochowa Univeristy of Technology Press.

UM (2011). Urząd Miejski w Wałbrzychu. Uchwała Nr V/23/11 z dnia 18 stycznia 2011 roku zmieniajaca Uchwate Nr LIX/511/10 Rady Miejskiej Wałbrzycha z dnia 10 listopada 2010 roku w sprawie przeprowadzenia referendum gminnego na wniosek mieszkańców [Municipal Office in Wałbrzych. Resolution No V/23/11 from 18th January 2011 changing the resolution No LIX/511/10 of City Council in Wałbrzych from 10th November 2010 concerning the holding of gmina referendum on the request of inhabitants]. Retrieved from http:// bip.um-walbrzych.dolnyslask.pl/ dokument.php?iddok=5856\&idmp $=254 \& r=0$.

YouTube (2010). Patryk Wild o wodzie w Watbrzychu [Patryk Wild about water in Wałbrzych]. Retrieved from http://www.youtube.com/watch?v=zx90dZOFz3c. 